\title{
Homeorhesis during Lactation Period in Dairy Cow and Buffaloes
}

\author{
Aamrapali Bhimte* \\ College of Veterinary Science and A. H. Mhow, NDVSU, India \\ *Corresponding author
}

\section{A B S T R A C T}

\begin{tabular}{|l|}
\hline Ke y w o r d s \\
Homeorhesis, \\
Lactation period, \\
$\begin{array}{l}\text { Dairy cow and } \\
\text { Buffaloes }\end{array}$ \\
\hline Article Info \\
\hline $\begin{array}{l}\text { Accepted: } \\
\text { 20 January } 2021 \\
\text { Available Online: } \\
\text { 10 February } 2021\end{array}$ \\
\hline
\end{tabular}

\section{Introduction}

Homeorhesis is the second type of control in partitioning nutrients. We define homeorhesis as the orchestrated or coordinated changes in metabolism of body tissues necessary to support a physiological state, or Orchestrated changes for the priorities of a physiological state, /.'e coordination of metabolism in various tissues to support a physiological state. The Greek derivation of homeorhesis is "uniform-flow" ${ }^{[2]}$. Hence, this is consistent with our definition, since homeorhetic regulation involves a coordination of metabolism to insure a uniform flow of nutrients in support of a physiological state. An alternative word that would be equally appropriate is the term "teleorhesis" ${ }^{\text {"[3]. The }}$
Perhaps the most pronounced example of homeorhesis would be in a dairy cow where initiation of lactation dramatically alters metabolism of many maternal organs in order that the mammary gland be supplied with nutrients necessary for synthesis of milk ${ }^{[1]}$. Homeorhesis as the "tendency to home on to a direction or pathway of change" (i.e., partitioning of nutrients to muscle during physiological state of growth), whereas homeostasis was defined as maintenance of equilibrium within a physiological state (i.e., thermoregulation of intake).

\section{Nutrient partitioning during lactogenesis}

Partitioning of the absorbed nutrients depends primarily upon the physiological status of the 
animals, rather than physiological needs of the various tissues and to a lesser extent upon the composition and physical form of the diet ingested by the dairy animals. The functional mammary gland is one of the most highly differentiated and metabolically active tissues in the body ${ }^{[15] .}$ Lactogenesis signals the shift from 'uterine nutrient transfer to fetus' to 'neonatal nourishment' at the mammary gland. Thus, at partitioning, the mammary gland achieves metabolic priority over other tissues to perform the synthesis and secretion of milk. The period of lactation in which the animal's ability to coordinate partitioning of nutrients assumes the most critical role is during the onset and development of copious milk secretion. Endocrine system is very active in nutrients partitioning through its influence on the anabolic and catabolic processes at the tissue level. At the initiation of lactation, marked alterations in the general partitioning of nutrients and metabolism of the whole animal must occur to accommodate demands of the mammary gland.

Partitioning of nutrients in dairy animals during different phases of lactation cycle, and thereby the need of nutrients according to stage of lactation is important to achieve maximum genetic potential for milk production and reproduction in dairy animals. During early part of lactation, dry matter intake remains suboptimum thus dairy cow is unable to meet out production requirements though intake. The nutrient needs of the mammary gland are of such magnitude relative to total metabolism in a high producing dairy cow that the cow should be considered an appendage on the udder rather than the reverse ${ }^{[9]}$. Due to depleting body stores during early lactation, dairy cows and buffaloes are found more susceptible for metabolic disorders/diseases, reproductive failure, poor immune status, poor body condition etc. the lactation cycle commercially and feeding dairy animals accordingly is very much important for a dairy farmer to run a successful dairy farm. The partitioning of nutrients to various body tissues involves two types of regulation, "Homeostasis" and "Homeorhesis". Homeostatic control involves maintenance of physiological equilibrium or constant conditions in the internal environment. Homeorhesis is the second type of control in partitioning nutrients.

\section{Metabolic adaptation during homeorhesis}

\section{Glucose metabolism by liver and kidney}

Liver is the major site of glucose production in dairy animals. Meeting the increased demand for glucose to synthesis lactose in mammary gland requires a two- to threefold increase in hepatic glucose production. Lactation is not just a function of the mammary gland. Commencement and maintenance of a successful lactation are dependent on alterations in many, perhaps even most, maternal tissues such that nutrients are partitioned to the mammary gland.

Liver contains some reserves of glucose as glycogen but these are trivial compared with the need for glucose, hence requirement is met by increased gluconeogenesis ${ }^{[7]}$. This is achieved through three mechanisms: Thus, regulation of nutrient partitioning by homeorhetic and homeostatic mechanisms is extremely important in insuring a high rate of milk production. Gluconeogenesis is stimulated by $\mathrm{GH}^{[3]}$ and increases four-fold in superior lactating cows p.p. The uptake of glucose by non-mammary tissue is reduced, and the oxidation of glucose is diminished, both of which direct the spared glucose to milk production ${ }^{[4]}$. These modifications in glucose metabolism are caused by altered hormonal concentrations and responses to homeostatic signals. A portion of the increase in liver gluconeogenic rates is from the 
increased intake when lactation commences

[20] but total glucose synthesized per day increases even if a constant intake is maintained. The preference of other body tissues for nutrients to be oxidized for energy also is altered to allow partitioning of a greater percentage of glucose to the mammary gland. At day 30 prepartum, 34\% of the total glucose turnover is oxidized to $\mathrm{CO}_{2}$, whereas this decreases to only 8 to $9 \%$ by day 7 of lactation

The kidneys also make minor contribution to glucose production through gluconeogenesis. However, neither the size of the organ nor the activities of its key gluconeogenic enzymes alter with lactation ${ }^{[8] .}$. The liver is also major site of lipid metabolism. During early lactation, supply of fatty acid to the liver is increased as a result of a rise in the unesterified fatty acid concentration in the blood (due to increased lipolysis) and the increase in blood flow to the liver.

\section{Lipid Metabolism by adipose tissue and skeletal muscle}

The physiological changes in dairy animals before parturition prepare the adipose tissues for the massive release of fatty acids, and accordingly, the mammary gland is prepared for receiving the increased supply of nutrients. At parturition there is massive mobilization of fatty acids from adipose tissues and consequently a dramatic rise in plasma free fatty acids [13] simultaneously, there is a considerable increase in the activity of the enzyme lipoprotein lipase in the mammary gland, as a preparatory step for the cleaving long chain fatty acids from the circulating triglycerides. Body energy reserves are predominantly in the form of lipids stored in adipose tissue. The adipocyte has only two major functions synthesis of lipids and mobilization of lipids. During the early part of lactation, adipose tissues witness a high rate of lipolysis and a very low rate of lipogenesis and the dairy animal is in negative energy balance. A cow in early lactation can even lose 20 to $50 \mathrm{~kg}$ of fat in 6 weeks. Optimal nutrition is important to exploit dairy animals genetically for production and reproduction. Losing more fat from body reserve indicates suboptimum nutrition and thus an animal may not be able to show its full potential for milk production. In this way, a dairy farmer faces hidden losses in milk production. To address this issue, supplementation of bypass fat is safe and has high caloric value use as good energy source to improve production and reproductive performance.

\section{Skeletal muscle}

A loss of skeletal muscle protein during lactation has been reported. The limited data available suggest that this is primarily due to an increase in protein degradation with little or no fall in protein synthesis ${ }^{[23]}$. Amino acids released from muscle are probably used either for protein synthesis in the mammary gland or gluconeogenesis in the liver. It is perhaps surprising that there is no fall in protein synthesis in muscle during lactation for this would be a means of conserving energy.

\section{Endocrine control of homeorhesis}

The endocrine control of nutrient partitioning to support pregnancy and lactation is a key issue of the homeorhetic regulation of transitional high yielding dairy cows. The high demand of nutrients for milk production at insufficient DMI requires careful allocation, which is (amongst others) predominantly regulated by changes of $\mathrm{GH}$, insulin, and IGF-1 concentrations and insulin resistance (IR) in selected tissues such as striated muscle and fat tissue ${ }^{[2,6,28,29,12]}$. As a consequence of these hormonal adjustments, 
flux rates of important nutrients are changed with the priority being milk production.

\section{Changes in hormonal concentration}

\section{Placental lactogen}

Placental lactogen, secreted by the conceptus, may be involved in homeorhetic control of maternal metabolism during pregnancy. In many species, including ruminants, placental lactogen concentrations in maternal serum are high during the last one-third of pregnancy ${ }^{[14,}$ 17, 18], coinciding with the period of rapid growth of the fetus. Mammary, adipose, and liver are among the tissues in which membrane receptors for placental lactogen have been reported ${ }^{[11,14]}$.

\section{Estrogen and progesterone}

Estrogens and progesterone also may participate as homeorhetic controls of nutrient partitioning during pregnancy. Changing the estrogen to progesterone ratio alters blood supply to the uterus and, thus, could affect nutrient availability to the fetus ${ }^{[10]}$. Since coordinated responses of maternal tissues are essential to support pregnancy, it is not surprising that estrogen, progesterone, and placental lactogen all play a positive role in growth of mammary glands (see review by De Louis et al., ${ }^{[16]}$. Progesterone concentrations in the blood begin to decrease gradually during the last weeks of pregnancy and then decrease precipitously immediately prepartum. As a result the progesterone inhibition on mammary differentiation is released. Simultaneously, estrogens are increased in the maternal circulation, and this is followed by the prepartum surge in prolactin.

\section{Prolactin}

Prolactin represents one of the key components of the "push" necessary for final stages of differentiation that result in mammary tissue acquiring the ability to synthesize milk components ${ }^{[19]}$. Prolactin is released as a result of suckling or a milking stimulus, and in dairy cows the magnitude of the release decreases as lactation progresses [26]. This release could be nature's way to reinforce needs of the mammary gland and, hence, those of the nursing neonate. Lactation results in an increase in serum prolactin, the primary lactogenic hormone.

Prolactin is involved in the development and differentiation of mammary gland. Blocking the prepartum release of prolactin in dairy cows with the specific drug results in a 40 to 50 per cent reduction in subsequent milk production and this effect is overcome by simultaneous administration of exogenous prolactin. Several investigators have proposed that prolactin coordinates lipid metabolism in adipose and liver tissue in a manner to partition nutrients to the mammary gland. Blocking the release of prolactin during lactogenesis or in early lactation produces not only the negative effects on mammary synthesis of milk but also results in an increase in adipose and liver pathways of lipid synthesis as well as reduction in the rates of lipid mobilisation from adipose tissues.

\section{Insulin}

During early lactation serum insulin concentration falls in cows, and later recovers as lactation progress and milk yield fall. Insulin is the major anabolic hormone of the body promoting lipid synthesis and inhibiting lipolysis in adipose tissues, promoting protein synthesis and inhibiting proteolysis in muscle, stimulating glucose uptake by muscles, inhibiting gluconeogenesis in the liver ${ }^{[25]}$. Although mammary cells from cow posses insulin receptors, insulin does not appear to have direct effect on mammary cells during lactation in cows, hence a fall in serum insulin 
should not have any deleterious effects on the mammary gland itself. Insulin appears to be required for the induction of lactogenesis in mammary tissues from cows and water buffalo.

\section{Glucagon}

Glucagon antagonises some actions of insulin and the serum insulin: glucagon ratio is thought to be important in the control of liver metabolism [27]. Glucagon stimulates gluconeogenesis and glycogenolysis whereas insulin inhibits these fluxes.

\section{Growth hormone}

During early lactation the concentration rises and then falls during later stages when milk yield falls. Growth hormone promotes the production of insulin-like growth factors (somatomedins) by the liver and these may have effects on the mammary gland. The action of growth hormone with respect to protein metabolism is anabolic i.e. preserving the protein reserves particularly during energy deficiency by inhibiting proteolysis and stimulating the incorporation of amino acids in to the tissues ${ }^{[22]}$. As far as lipid metabolism is concerned, growth hormone stimulates lipolysis, and inhibits lipogenesis in the adipose tissues and subsequently stimulate the nutrient mobilisation, by diverting glucose and fatty acids away from tissue deposition towards mammary gland, during lactation. It has been reported that changes in growth hormone levels in blood are positively correlated with changes in milk yield.

\section{Glucocorticoids}

During early lactation the concentration of glucocorticoids rises and then falls during later stages when milk yield falls ${ }^{[24]}$. They enhance the action of insulin on lipogenesis and antagonise the action of insulin on glucose utilisation. They also help in gluconeogenesis.

\section{Catecholamin}

Stimulation of sympathetic nervous system leads to the release of noradrenalin in adipose tissues which increases lipolysis and inhibits lipogenesis. Noradrenalin interacts with betareceptors on the surface of the adipocyte resulting in a series of reaction which culminate in the activation of hormonesensitive lipase and hence increased lipolysis [24].

In conclusion the priority of milk production is one important consequence of this homeorhetic regulation with possible constraints on other physiological functions. Homeorhesis provides the proper balance of nutrients to mammary gland during transition period and lactation. This will help to maintain optimal level of milk production despite animal's nutritional or physiological state.

\section{References}

1. Agnes R, Yan T. Impact of recent research on energy feeding system for dairy cattle. Livestock Production Science 2000; 66:197-215.

2. Bauman D, Currie, E. Partitioning of nutrients during pregnancy and lactation. Journal of Dairy Science 1980; 63:15141529.

3. Bauman D, Peel C, Steinhour W, Reynolds P, Tyrell H, Brown A, Haaland G. Effect of bovine somatotropin on metabolism of lactating dairy cows: Influence on rates of irreversible loss and oxidation of glucose and nonesterified fat acids. Journal of Nutrition 1988; 118:1031-1040.

4. Bauman D. Regulation of nutrient 
portioning during lactation: Homeostasis and homeorhesis revisited. In P. Cronjé (Ed.), Ruminant Physiology: Digestion, Metabolism, Growth and Reproduction 2000; pp. 311-328. CAB International

5. Baumgard L, Collier R, Bauman D. A 100-Year Review: Regulation of nutrient partitioning to support lactation. Journal of Dairy Science 2017; 100:1035210366.

6. Bell A, Bauman D, Currie B. Regulation of nutrient partitioning and metabolism during pre- and postnatal growth. Journal of Animal Science 1987; 65(Suppl. 2):186-212.

7. Bell A, Bauman D. Adaptation of glucose metabolism during pregnancy and lactation. Journal of Mammary Gland Biology and Neoplasia 1997; 2:265-278.

8. Bennink MR, Mellenberger RW, Frobish RA, Bauman DE. Glucose oxidation and entry rate as affected by the initiation of lactation. Journal of Dairy Science 1972; 55:712.

9. Boisclair Y, Wesolowski S, Kim J, Ehrhardt R. Roles of growth hormone and leptin in the periparturient dairy cow. In K. Sejrsen, T. Hvelplung, \& $M$. Nielsen (Eds.), Ruminant Physiology. Digestion, metabolism and impact of nutrition on gene expression, immunology and stress. Wageningen Academic Publishers 2006; (pp. 327344).

10. Caton D, Abrams RM, Lackore LK, James GB, Barron DH. Effects of progesterone administration on the rate of uterine blood flow of early pregnant sheep. Page 286 in Foetal and neonatal physiology. R. S. Comline, K. W. Cross, G. S. Dawes, and P. W. Nathanielsz, ed. Cambridge University Press, Cambridge 1973.

11. Chan JSD, Robertson HA, Friesen HG. The purification and characterization of ovine placental lactogen. Endocrinology 1976; 98:65.

12. Chilliard Y, Bocquier F, Doreau M. Digestive and metabolic adaptations of ruminants to under-nutrition, and consequences on reproduction. Reproduction Nutrition Development 1998; 38:131-152.

13. Contreras G, Strieder-Barboza C, Raphael W. Adipose tissue lipolysis and remodeling during transition period of dairy cows. Journal of Animal Science and Biotechnology 2017; 8, 41.

14. Currie WB, Kelly PA, Friesen HG, Thorburn GD. Caprine placental lactogen: Levels of prolactin-like and growth hormone-like activities in the circulation of pregnant goats determined by radioreceptor assays. Journal of Endocrinology 1977; 73:215.

15. Davis CL, Bauman DE. General metabolism associated with the synthesis of milk. Page 1 in Lactation: A comprehensive treatise. Vol. 2. B. L. Larson and V. R. Smith, ed. Academic Press, New York, NY 1974.

16. Delouis CJ, Djiane LM, Houdebin, Terqui M. Relation between hormones and mammary gland function. Journal of Dairy Science 1980; 63: 1492.

17. Hayden TJ, Thomas CR Forsyth IA. Effect of number of young born (litter size) on milk yield of goats: Role for placental lactogen. Journal of Dairy Science 1979;62:53

18. Kelly PA, Tsushima T, Shiu RPC, Friesen HG. Lactogenic and growth hormonelike activities in pregnancy determined by radioreceptor assays. Endocrinology 1976; 99:765.

19. Kuhn NJ. Lactogenesis: The search for trigger mechanisms in different species. Page 165 in Comparative aspects of lactation. M. Peaker, ed. Academic Press, New York, NY 1977.

20. Lindsay DB. Changes in the pattern of 
glucose metabolism in growth, pregnancy and lactation in ruminants. Proc. Nutr. Soe. 1971; 30:272.

21. Opsina P, Nydam D, Stokol T, Overton T. Association of elevated nonesterified fat acids and $\beta$-hydroxybutyrate concentrations with early lactation performance and milk production in transition dairy cattle in the northeastern United States. Journal of Dairy Science 2010; 93:1596-1603.

22. Posner BI, Kelly PA, Shin RPC, Friesen HG. Studies of insulin, growth hormone and prolactin binding: Tissue distribution, species variation and characterization 1974.

23. Reid I. Fat liver in dairy cows-incidence, severity, pathology and functional consequences. Bovine Practitioner 1982; 17:149-150.

24. Smith VG, Beck TW, Convey EM, Tucker HA. Bovine serum prolactin, growth hormone, cortisol and milk yield after ergocryptine. Neuroendocrinology
15:172. Endocrinology 1974; 95:521.

25. Trenkle A. Relation of hormonal variations to nutritional studies and metabolism of ruminants. Journal of Dairy Science 1978; 61:281.

26. Tucker HA. General endocrinological control of lactation. Page 277 in Lactation: A comprehensive treatise. Vol. 1. B. L. Larson and V. R. Smith, ed. Academic Press, New York, NY 1974.

27. Vasilatos R, Wangsness PJ. 1979. Plasma hormone and metabolite changes associated with two periods of lactation in high-producing dairy cows. Journal of Dairy Science 1979; 62 (Suppl 1): 230

28. Vernon R. Endocrine control of metabolic adaptation during lactation. Proceedings of the Nutrition Society 1989; 48, 23-32.

29. Vernon R, Pond C. Adaptation of maternal adipose tissue to lactation. Journal Mammary Gland and Biology of Neoplasia 1997; 2:231-241.

\section{How to cite this article:}

Aamrapali Bhimte. 2021. Homeorhesis during Lactation Period in Dairy Cow and Buffaloes. Int.J.Curr.Microbiol.App.Sci. 10(02): 2432-2638. doi: https://doi.org/10.20546/ijcmas.2021.1002.288 